\title{
Role of Transcription Factor 7 like 2 and Silent Information Regulator 1 Genes in the Development of Cardiovascular Complications in a Group of Egyptian Patients with Chronic Kidney Disease
}

\author{
Doaa Mamdouh $^{1 *(D)}$, Hanan Shawky ${ }^{1}$, Nihal Moustafa El-Assaly ${ }^{1}$, Samia El-Shishtawy ${ }^{2}$, Nevine Sherif $^{2}$, Amna Metwaly $^{3}$, Asmaa $^{2}$ \\ Mohamed Fteah ${ }^{1}$ \\ ${ }^{1}$ Department of Clinical Chemistry, Theodor Bilharz Research Institute, Giza, Egypt; ${ }^{2}$ Department of Nephrology, Theodor \\ Bilharz Research Institute, Giza, Egypt; ${ }^{3}$ Intensive Care Unit, Theodor Bilharz Research Institute, Giza, Egypt
}

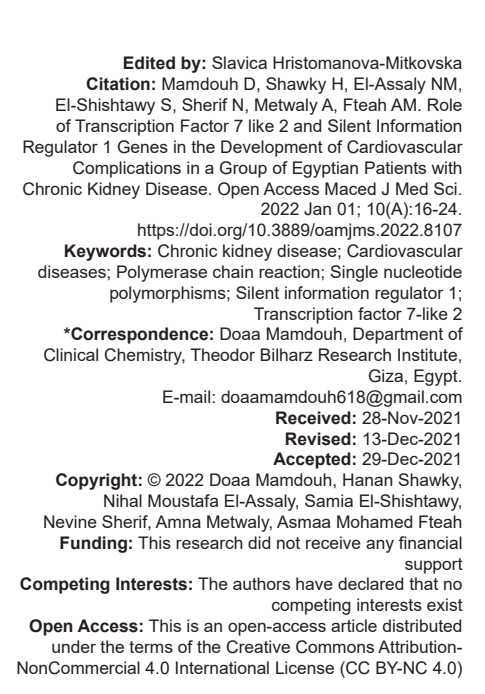

\begin{abstract}
BACKGROUND: Sirtuins silent information regulator 1 (SIRT) is histone deacetylases that act as antioxidants and involved in the pathogenesis of cardiovascular diseases (CVD) which are the major complications of chronic kidney disease (CKD). Transcription factor 7-like 2 (TCF7L2) genetic polymorphisms could contribute to the risk of CVD as TCF7L2 proteins regulate vascular remodeling

AIM: We tried to demonstrate the role of genetic polymorphisms: rs7069102 and rs10823108 in SIRT1 gene and rs7903146 in TCF7L2 gene in the development of CVD in CKD Egyptian patients.

METHODS: This study included 120 CKD patients (60 with CVD and 60 without CVD) and 60 age and sex-matched healthy subjects as a control group. Routine laboratory investigations were performed and genotyping for candidate single nucleotide polymorphisms was done by Taqman-real-time polymerase chain reaction.

RESULTS: The frequency of the $C$ allele of rs7069102 was significantly higher in CKD patients with CVD as compared to the normal control group $(p<0.001)$ and as compared to CKD patients without CVD $(p<0.001)$. Percentages of AG and GG genotypes of rs 10823108 were significantly higher in CKD patients with CVD as compared to the normal control group ( $p=0.002,0.035$, respectively). The frequency of the T allele of rs 7903146 was significantly higher in CKD patients with CVD as compared to the normal control group $(p<0.001)$

CONCLUSION: We found that C allele of rs7069102, GG and AG genotypes of rs10823108 in the SIRT1 gene and T allele of rs7903146 in TCF7L2 gene have a potential role in the pathogenesis and the risk of CVD development in CKD Egyptian patients.
\end{abstract}

\section{Introduction}

Chronic kidney disease (CKD) is a common chronic disease affecting many people worldwide. CKD is diagnosed by reduction of estimated glomerular filtration rate (eGFR) $<60 \mathrm{~mL} / \mathrm{min} / 1.73 \mathrm{~m}^{2}$ for at least 3 months [1]. The global incidence and prevalence of CKD had markedly increased over the past 20 years. Mortality due to CKD has also increased dramatically [2]. End-stage renal disease (ESRD) is usually associated with other chronic diseases such as diabetes and hypertension. The most important cause for the increased morbidity and mortality among ESRD patients is cardiovascular diseases (CVD); the prevalence of CVD is significantly elevated in patients with CKD that can't be attributed to traditional risk factors such as diabetes and hypertension alone [3]. Several investigators had studied the risk of CVD to know the exact pathogenic mechanisms that could explain the higher risk of CVD in CKD patients. The identification of genetic factors that are associated with the pathogenesis of CVD in CKD patients could help in the improvement of diagnostic tools and risk assessment of CVD in CKD patients as well as modification of therapy [4].

The transcription factor 7-like 2 (TCF7L2) gene is located on chromosome 10q25.3, which contains 215,863 bases, including 17 exons, encoding 596 amino acids. The TCF7L2 is a member of the TCF/lymphoid enhancer factor family. It is a downstream regulator in the Wnt signaling pathway, which regulates the proliferation of pancreatic beta-cell; thus, it stabilizes glucose levels in the body through the regulation of insulin secretion. Interestingly, TCF7L2 protein encoded by the TCF7L2 gene and could increase the risk of CVD as it is a major regulator in the endothelial cell growth proliferation, and thus, it affects vascular remodeling [5]. TCF7L2 gene is one of the candidate genes predisposing to diabetes. Many single nucleotide polymorphisms (SNPs) in the TCF7L2 gene were associated with increased risk of type 2 diabetes, especially the SNP: rs7903146, which 
is located in the intron 3. This SNP is also linked to coronary atherosclerosis in diabetic patients [6].

Sirtuins silent information regulator (SIRT1) is a family of histone deacetylases regulating gene expression [7]. Sirtuin proteins are categorized according to their subcellular localization. SIRT1 is a nuclear protein and is also present in the cytoplasm [8]. Due to their ability to target post-translational histone modifications, sirtuins are vital for many processes such as DNA repair and antioxidant activity through promoting gene silencing and transcriptional repression. SIRT1 is mainly a nuclear protein; however, it can exit the nucleus into the cytoplasm under ischemic conditions [7], [9]. SIRT1 was reported to be associated with oxidative stress in an ischemic environment through the repression of its downstream targets [5]. Some stress-related genes are targets of the SIRT1 gene, such as mTOR, PI-3K, PPAR- $\gamma$, and p53. SIRT1 has been recognized as a regulator of the cardiovascular system, and it has anti-atherosclerotic capabilities through the prevention of stress-related complications. Activation of SIRT1 function by drugs was reported to reduce oxidative injury-induced endothelial cell death [10]. Accordingly, we tried to investigate the role of SNPs of rs7069102 and rs10823108 in the SIRT1 gene as well rs7903146 in the TCF7L2 gene in the development of CVD in CKD Egyptian patients.

\section{Methodology}

\section{Ethical approval}

Following research ethics, approval from the Institutional Research Board (IRB) of Theodor Bilharz Research Institute (TBRI), (FWA00010609) was obtained before performing the study; the serial number of the protocol is PT (637). Informed consent for the study was obtained from all research participants under the supervision of the IRB. The study was conducted following the ethical principles described by the 1964 Declaration of Helsinki and its later amendments.

\section{Study design and participants}

This case-control study was conducted from June 2021 till November 2021. Corresponding to power analysis (80\% power with $95 \%$ confidence interval), the study groups consisted of 180 age and sex-matched subjects, divided into three groups as follows:

- Group I: included 60 CKD patients with CVD in the form of coronary artery disease, left ventricular hypertrophy, or congestive heart failure

- Group II: included 60 CKD patients without CVD as a pathological control group
CKD patients were subjected to full history taking and clinical examination

- $\quad$ They were stratified according to disease severity by calculation of eGFR using Modification of Diet in Renal Disease equation

- $\quad$ Body mass index (BMI) was calculated by dividing weight by height square $\left(\mathrm{kg} / \mathrm{m}^{2}\right)$ and categorized according to the World Health Organization recommendations

- $\quad$ All ESRD patients were recruited from the dialysis unit of Theodor Bilharz Research Institute and they were on regular hemodialysis

- CVD were diagnosed by the electrocardiogram and/or echocardiography Patients who had histories of congenital heart disease, rheumatic heart disease, recent myocardial infarction, unstable angina pectoris, acute heart failure, malignancies, major trauma or surgery in the previous 6 months, acute or chronic infectious disease, any kind of immune-mediated disease, and those who were below 18 years old were excluded

- Group III: 60 ethnically-matched donors with no prior medical or family history of CKD were recruited for comparison to a healthy population, randomly selected from individuals attending the outpatient clinic for other reasons. They had normal liver and kidney function tests with no history of hypertension, alcohol abuse, or diabetes.

\section{Laboratory investigations}

$4 \mathrm{~mm}$ of whole blood samples were obtained after $12 \mathrm{~h}$ of fasting into plain tubes, centrifuged for $5 \mathrm{~min}$ at 4500 rotations per minute and then serum was stored at $-20^{\circ} \mathrm{C}$ till the time of analysis. The following biochemical parameters were determined in CKD patients and normal control group by standard biochemical laboratory methods: kidney and liver function tests including serum urea, creatinine, uric acid, calcium, phosphorus, sodium, potassium, alanine aminotransferase, aspartate aminotransaminase, total protein, serum albumin, total cholesterol, and triglycerides.

Routine laboratory tests were assayed by the AU 480 chemistry analyzer - Beckman Coulter* in the clinical chemistry department at TBRI Hospital.

\section{Analysis of SNPs} in samples

DNA extraction and quantification of DNA

$2 \mathrm{~mm}$ of whole blood samples were collected into a sterile EDTA vacutainer tube and stored at $-20^{\circ} \mathrm{C}$. Extraction of genomic DNA from peripheral blood

* Beckman Coulter Ireland, Inc.: 250 S. Kraemer Blvd., Brea, CA 92821 USA. 
leucocytes of EDTA anticoagulated blood was done using ThermoFisher Scientific GeneJET Whole Blood Genomic DNA Purification Mini Kit** (Catalog number: K0781, supplied by Clinilab, Egypt). Quantity of DNA and purity of samples were assessed using Qubit Fluorometric quantification assays (ThermoFisher Scientific, USA**).

\section{Genotyping assays}

Real-time polymerase chain reaction (PCR) with sequence-specific primers was used to define the genetic polymorphism (rs7903146) of the TCF7L2 gene and two SNPs (rs10823108 and rs7069102) of the SIRT1 gene.

Amplification of the extracted DNA and realtime PCR allelic discrimination assay was done using TaqMan® SNP Genotyping Assays (Catalog number: 4351379, supplied by Clinilab, Egypt) and were analyzed on StepOne PCR systems (Applied Biosystems ${ }^{\S 2}$ ) according to the protocol proposed by Kristiansen et al., 2001 [11].

The thermal cycling conditions were programmed as the following:

$95^{\circ} \mathrm{C}$ for $10 \mathrm{~min}, 50$ cycles of $92^{\circ} \mathrm{C}$ for 10 $\mathrm{s}$, and $60^{\circ} \mathrm{C}$ for $1 \mathrm{~min}$. Allelic discrimination was performed by the Applied Biosystems Step One Real-Time PCR system software. Molecular studies were performed in the molecular research unit in the chemical pathology department, Kasr El-Ainy hospital- Cairo university.

\section{Statistical analysis}

Data were coded and entered using the statistical package for the Social Sciences version 26 (IBM Corp., Armonk, NY, USA). Data were summarized using mean and standard deviation for quantitative variables and frequencies (number of cases) and relative frequencies (percentages) for categorical variables. Comparisons between groups were done using unpaired t-test when comparing 2 groups and analysis of variance with multiple comparisons post-hoc test when comparing more than 2 groups in normally distributed quantitative variables while non-parametric Kruskal-Wallis test and Mann-Whitney test were used for non-normally distributed quantitative variables [12] For comparing categorical data, Chi-square $\left(\chi^{2}\right)$ test was performed. The exact test was used instead when the expected frequency is <5 [13]. Genotype and allele frequencies were compared between groups. Odds ratio (OR) with 95\% confidence intervals was calculated using binary logistic regression. $p<0.05$ were considered statistically significant.

\footnotetext{
** ThermoFisher Scientific, Inc.: 81 Wyman St. Waltham CA. 02451 USA.

$\S$ Applied Biosystems: Campus (Foster City, California). 850 Lincoln Centre Dr. Foster City, CA. 94404 USA
}

\section{Results}

\section{Demographic, clinical, and laboratory data of the study groups}

The demographic, clinical, and laboratory data of the three studied groups are summarized in Table 1. We found that CKD patients with CVD had significantly higher BMI and presence of chronic diseases, namely diabetes mellitus and hypertension as compared to CKD patients without CVD ( $p<0.001)$. Duration of hemodialysis was significantly longer in CKD patients with CVD as compared to CKD patients without CVD $(p<0.001)$. Serum urea and creatinine were significantly increased in CKD patients with CVD as compared to the normal control group ( $p<0.001)$. Serum calcium and albumin were significantly decreased in CKD patients with CVD as compared to the normal control group ( $p<0.001)$. Fasting blood glucose levels were significantly increased in CKD patients with CVD as compared to CKD patients without CVD ( $p=0.024)$. Total cholesterol and triglycerides levels, as well as serum phosphorus levels, were significantly increased in CKD patients with CVD as compared to both CKD patients without CVD and the normal control groups $(p<0.001)$.

\section{Genotypic frequency and distribution of the studied SNPs among the study population}

The three studied genetic polymorphisms: rs7069102 and rs10823108 in the SIRT1 gene as well as rs7903146 in the TCF7L2 gene were studied and found to differ significantly among the three studied groups ( $p<0.001,0.001$, and 0.009 , respectively). The frequency of the studied SNPs is represented in Figures 1-3.

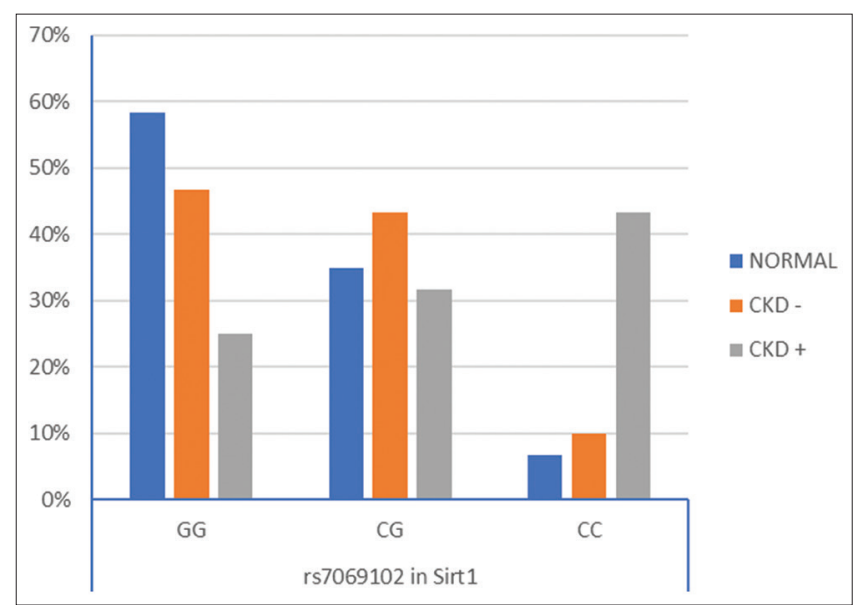

Figure 1: rs7069102 frequency in the study groups: Normal, chronic kidney disease (CKD) without cardiovascular diseases (CVD) (CKD-) and CKD with CVD (CKD+)

The percentage of CC genotype and C allele of rs7069102 in the SIRT1 gene were found to be significantly higher in CKD patients with CVD as 
Table 1: Demographic, clinical, and laboratory characteristics of the study population

\begin{tabular}{|c|c|c|c|c|}
\hline Items & CKD without CVD $(n=60)$ & CKD with CVD $(n=60)$ & Normal $(n=60)$ & p-value \\
\hline Age (years) ${ }^{\star}$ & $57.70 \pm 6.62$ & $56.88 \pm 6.70$ & $54.87 \pm 6.85$ & 0.062 \\
\hline \multicolumn{5}{|l|}{$\operatorname{Sex}^{\star \star}(\%)$} \\
\hline Male & $43(71.7)$ & $43(71.7)$ & $50(83.3)$ & \multirow[t]{2}{*}{0.229} \\
\hline Female & $17(28.3)$ & $17(28.3)$ & $10(16.7)$ & \\
\hline $\operatorname{BMI}\left(\mathrm{kg} / \mathrm{m}^{2}\right)^{*}$ & $25.03 \pm 4.47$ & $28.52 \pm 4.38$ & -- & $<0.001$ \\
\hline Weight $(\mathrm{kg})^{*}$ & $71.42 \pm 13.32$ & $83.42 \pm 12.46$ & -- & $<0.001$ \\
\hline Duration of dialysis (years) ${ }^{\star}$ & $6.62 \pm 3.24$ & $9.40 \pm 3.22$ & -- & $<0.001$ \\
\hline Systolic blood pressure $(\mathrm{mm} / \mathrm{Hg})^{*}$ & $132.35 \pm 12.55$ & $134.78 \pm 14.07$ & _- & 0.320 \\
\hline Diastolic blood pressure $(\mathrm{mm} / \mathrm{Hg})^{*}$ & $84.52 \pm 11.15$ & $84.83 \pm 8.54$ & -- & 0.862 \\
\hline Pulse/minute (number of beats) * & $78.27 \pm 11.52$ & $76.60 \pm 10.84$ & -- & 0.416 \\
\hline \multicolumn{5}{|l|}{ History of chronic disease ${ }^{\star \star}(\%)$} \\
\hline Diabetes mellitus & $11(18.3)$ & $10(16.7)$ & -- & $<0.001$ \\
\hline Hypertension & $28(46.7)$ & $15(25.0)$ & _- & \multirow[t]{4}{*}{$<0.001$} \\
\hline Systemic lupus erythematosis & $0(0.0)$ & $1(1.7)$ & -- & \\
\hline Behcet's disease & $0(0.0)$ & $2(3.3)$ & -- & \\
\hline No chronic disease & $16(26.7)$ & $6(10.0)$ & -- & \\
\hline \multicolumn{5}{|l|}{ Smoking ${ }^{\star *}(\%)$} \\
\hline Yes & $11(18.3)$ & $21(35.0)$ & -- & \multirow[t]{3}{*}{$<0.001$} \\
\hline No & $44(73.3)$ & $34(56.7)$ & -- & \\
\hline Ex-smoker & $5(8.3)$ & $5(8.3)$ & -- & \\
\hline \multicolumn{5}{|l|}{ CKD etiology** $(\%)$} \\
\hline Diabetic Nephropathy & $16(26.7)$ & $35(58.3)$ & -- & 0.001 \\
\hline Hypertensive Nephropathy & $29(48.3)$ & $13(21.7)$ & -- & 0.001 \\
\hline Analgesic Nephropathy & $2(3.3)$ & $1(1.7)$ & _- & 0.001 \\
\hline Obstructive Uropathy & $12(20.0)$ & $8(13.3)$ & _- & 0.001 \\
\hline Vasculitis & $0(0.0)$ & $3(5.0)$ & -- & 0.001 \\
\hline Polycystic kidney disease & $1(1.7)$ & $0(0.0)$ & _- & 0.001 \\
\hline \multicolumn{5}{|l|}{ Biochemical data* $(\%)$} \\
\hline Urea $(\mathrm{mg} / \mathrm{dl})$ & $88.52 \pm 20.64$ & $95.67 \pm 21.14 *$ & $25.08 \pm 7.68$ & $<0.001$ \\
\hline Creatinine (mg/dl) & $8.08 \pm 1.21$ & $7.81 \pm 1.39$ * & $0.72 \pm 0.14$ & $<0.001$ \\
\hline Calcium (mg/dl) & $8.73 \pm 0.78$ & $8.35 \pm 0.85 *$ & $10.34 \pm 1.01$ & $<0.001$ \\
\hline Phosphorus (mg/dl) & $4.62 \pm 1.28$ & $5.63 \pm 1.30$ 籸 & $3.70 \pm 0.55$ & $<0.001$ \\
\hline Uric acid (mg/dl) & $6.02 \pm 1.64$ & $5.69 \pm 1.66$ & -- & 0.271 \\
\hline Glucose $(\mathrm{mg} / \mathrm{dl})$ & $120.03 \pm 50.75$ & $141.83 \pm 53.55 \ddagger$ & -- & 0.024 \\
\hline Cholesterol (mg/dl) & $185.37 \pm 47.61$ & $239.47 \pm 64.47$ 粒 & $151.77 \pm 23.76$ & $<0.001$ \\
\hline Triglycerides (mg/dl) & $114.77 \pm 27.04$ & $148.02 \pm 38.12$ 籹 & $100 \pm 24.78$ & $<0.001$ \\
\hline Total protein ( $\mathrm{g} / \mathrm{dl})$ & $7.44 \pm 0.62$ & $7.40 \pm 0.90$ & $7.38 \pm 0.55$ & 0.894 \\
\hline Serum albumin (g/dl) & $3.74 \pm 0.41$ & $3.75 \pm 0.49$ * & $4.17 \pm 0.34$ & $<0.001$ \\
\hline ALT (IU/I) & $26.13 \pm 11.42$ & $28.35 \pm 13.40 *$ & $19.55 \pm 9.19$ & $<0.001$ \\
\hline AST (IU/I) & $25.10 \pm 12.26$ & $29.43 \pm 17.52 *$ & $22.02 \pm 6.52$ & 0.008 \\
\hline $\mathrm{Na}^{+}(\mathrm{mmol} / \mathrm{l})$ & $137.60 \pm 3.56$ & $138.07 \pm 3.50$ & -- & 0.471 \\
\hline $\mathrm{K}^{+}(\mathrm{mmol} / \mathrm{l})$ & $4.47 \pm 0.52$ & $4.33 \pm 0.62$ & -- & 0.176 \\
\hline
\end{tabular}

compared to the normal control group $(p<0.001$ and $<0.001$, respectively). Furthermore, the percentage of CC genotype and C allele of rs7069102 in the SIRT1 gene was significantly higher in CKD patients with CVD as compared to CKD patients without CVD $(p<0.001$ and $<0.001$ respectively). Regarding risk estimation for CVD development, for CKD patients with CVD, as compared to the normal control group, we found that rs7069102 CC genotype and $\mathrm{C}$ allele carriers are highly susceptible to developing cardiovascular complications than those with $(G G / C G)$ genotypes (for CC genotype OR =
15.167, 95\% Cl $=4.5-51.06$ and $\mathrm{p}<0.001)$ (Table 2). Furthermore, we found that CC genotype and $\mathrm{C}$ allele carriers of rs7069102 in the SIRT1 gene were 8.08 and 3.1 times more susceptible to develop CVD than non-CC variant carriers (for CC genotype $\mathrm{OR}=8.08$, $95 \% \mathrm{Cl}=2.7-23.9$ and $\mathrm{p}<0.001)($ Table 2$)$.

Regarding rs 10823108 in the SIRT1 gene; we found that percentage of both $A G$ and $G G$ genotypes was significantly higher in CKD patients with CVD as compared to the normal control group $(p=0.002$ and

Table 2: Frequency distribution of SIRT1 (rs7069102) genotypes and alleles among the three studied groups

\begin{tabular}{|c|c|c|c|c|c|c|}
\hline Genotype & Normal $(n=60)(\%)$ & CKD without CVD $(n=60)(\%)$ & \multicolumn{3}{|c|}{ CKD with CVD $(n=60)(\%)$} & \multirow{2}{*}{$\begin{array}{l}\mathrm{p} \text {-value } \\
<0.001\end{array}$} \\
\hline GG & $35(58.3)$ & $28(46.7)$ & $15(25.0)$ & & & \\
\hline CG & $21(35.0)$ & $26(43.3)$ & 19 (31.7) & & & \\
\hline \multirow[t]{2}{*}{$\mathrm{CC}$} & $4(6.7)$ & $6(10.0)$ & $26(43.3)$ & & & \\
\hline & Normal $(n=60)$ & CKD without CVD $(n=60)$ & $p$-value & OR & $95 \% \mathrm{Cl}$ & \\
\hline GG & $35(58.3)$ & $28(46.7)$ & Reference & & & \\
\hline CG & $21(35.0)$ & $26(43.3)$ & 0.260 & 1.548 & 0.724 & 3.309 \\
\hline $\mathrm{CC}$ & $4(6.7)$ & $6(10.0)$ & 0.365 & 1.875 & 0.482 & 7.300 \\
\hline Allele G & $91(75.8)$ & $82(68.3)$ & Reference & & & \\
\hline \multirow[t]{2}{*}{ Allele C } & $29(24.2)$ & $38(31.7)$ & 0.196 & 1.454 & 0.824 & 2.566 \\
\hline & Normal $(n=60)$ & CKD with CVD $(n=60)$ & $p$-value & OR & $95 \% \mathrm{Cl}$ & \\
\hline GG & $35(58.3)$ & $15(25.0)$ & Reference & & & \\
\hline CG & $21(35.0)$ & 19 (31.7) & 0.091 & 2.111 & 0.887 & 5.022 \\
\hline $\mathrm{CC}$ & $4(6.7)$ & $26(43.3)$ & $<0.001$ & 15.167 & 4.504 & 51.069 \\
\hline Allele G & $91(75.8)$ & $49(40.8)$ & Reference & & & \\
\hline \multirow[t]{2}{*}{ Allele C } & $29(24.2)$ & $71(59.2)$ & $<0.001$ & 4.547 & 2.612 & 7.914 \\
\hline & CKD without CVD $(n=60)$ & CKD with CVD $(n=60)$ & $\mathrm{p}$-value & OR & $95 \% \mathrm{Cl}$ & \\
\hline GG & $28(46.7)$ & $15(25.0)$ & Reference & & & \\
\hline CG & $26(43.3)$ & 19 (31.7) & 0.480 & 1.364 & 0.576 & 3.230 \\
\hline CC & $6(10.0)$ & $26(43.3)$ & $<0.001$ & 8.089 & 2.728 & 23.983 \\
\hline Allele G & $82(68.3)$ & $49(40.8)$ & Reference & & & \\
\hline Allele C & $38(31.7)$ & $71(59.2)$ & $<0.001$ & 3.127 & 1.841 & 5.310 \\
\hline
\end{tabular}




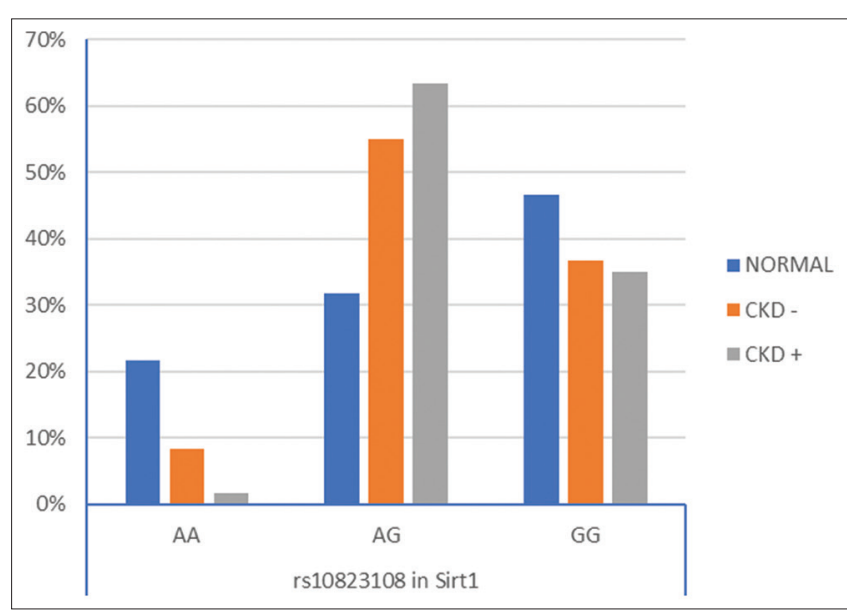

Figure 2: rs10823108 frequency in the study groups Normal, CKD without CVD (CKD-) and CKD with CVD (CKD+)

0.035, respectively). Furthermore, the rs10823108 AG genotype percentage was found to be significantly higher in CKD patients without CVD when compared to the normal control group $(p=0.012)$.

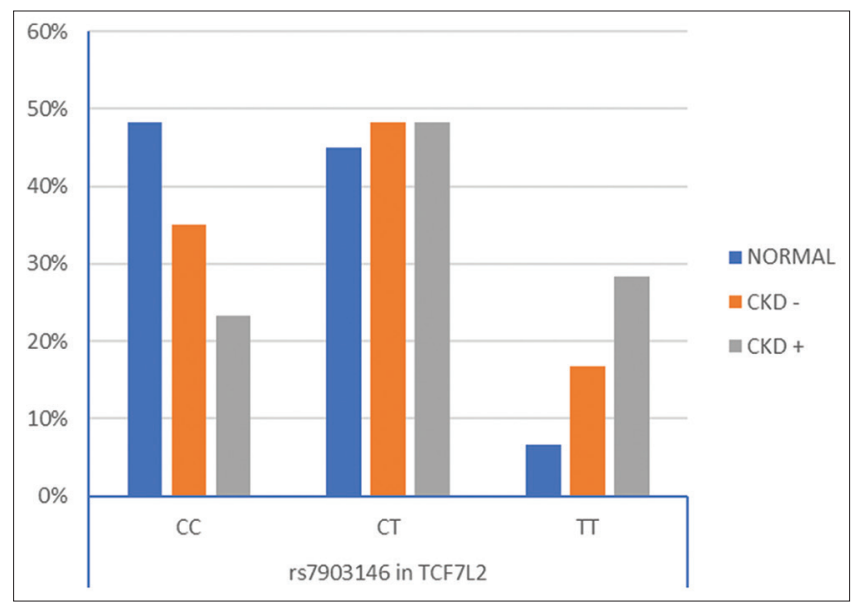

Figure 3: rs7903146 frequency in the study groups Normal, CKD without CVD (CKD-) and CKD with CVD (CKD+)

Carriers of GG genotypes in the SIRT1 gene (rs10823108) were found to be more susceptible to develop CVD than those with non-GG variant $(\mathrm{OR}=$ $9.7,95 \% \mathrm{Cl}=1.18-80.5$ and $p=0.035$ ) (Table 3).
Moreover, the distribution of the homozygous TT genotype and T allele frequencies in the rs7903146 locus of the TCF7L2 gene among the three groups showed a significant difference compared to homozygous type CC in CKD patients with CVD as compared to the normal control group ( $p=0.001$ and $<0.001$, respectively). The TT genotype of rs7903146 showed a significantly higher risk of cardiovascular complications as compared with carriers of non-TT variant (for TT genotype $\mathrm{OR}=8.8,95 \% \mathrm{Cl}=2.4-31.1$ and $p=0.001$ ) (Table 4).

3.3 Correlation between individual SNPs and other parameters:

We assessed the relation between SIRT1 and TCF7L2 genetic polymorphisms and the laboratory as well as the clinical parameters. We found that there is a significant positive relation between serum glucose level and CC genotype of rs7069102 in the SIRT1 gene $(p=0.034)$ (Table 5). For rs10823108 in the SIRT1 gene, we found that there is a significant positive relation between serum phosphorus level and AG genotype of rs10823108 in the SIRT1 gene $(p=0.037)$ (Table 6). For rs7903146 in the TCF7L2 gene, we found that TT genotype carriers of rs7903146 in TCF7L2 had a significantly higher duration of dialysis $(p=0.001)$. Moreover, we found a significant positive relation between serum triglycerides level and TT genotype of TCF7L2 gene $(p=0.030)$ (Table 7$)$.

\section{Discussion}

Genetic factors are major players in the development of cardiovascular complications especially in CKD patients since CVD represents the main cause of death in CKD patients. SIRT1 is a vital regulator of inflammation and smooth muscle proliferation in the heart. Expression of SIRT1 protein is markedly diminished in inflamed endothelial cells. We investigated

Table 3: Frequency distribution of SIRT1 (rs10823108) genotypes and alleles among the three studied groups

\begin{tabular}{|c|c|c|c|c|c|c|}
\hline Genotype & Normal $(n=60)(\%)$ & CKD without CVD $(n=60)(\%)$ & \multicolumn{3}{|c|}{ CKD with CVD $(n=60)(\%)$} & \multirow{2}{*}{$\begin{array}{l}\text {-value } \\
0.001\end{array}$} \\
\hline AA & $13(21.7)$ & $5(8.3)$ & $1(1.7)$ & & & \\
\hline AG & 19 (31.7) & $33(55.0)$ & $38(63.3)$ & & & \\
\hline \multirow[t]{2}{*}{ GG } & $28(46.7)$ & $22(36.7)$ & $21(35.0)$ & & & \\
\hline & Normal $(n=60)$ & CKD with CVD $(n=60)$ & p-value & OR & $95 \% \mathrm{Cl}$ & \\
\hline AA & $13(21.7)$ & $1(1.7)$ & Reference & & & \\
\hline AG & 19 (31.7) & $38(63.3)$ & 0.002 & 26.000 & 3.161 & 213.851 \\
\hline GG & $28(46.7)$ & $21(35.0)$ & 0.035 & 9.750 & 1.181 & 80.515 \\
\hline Allele A & 45 (37.5) & $40(33.3)$ & Reference & & & \\
\hline \multirow[t]{2}{*}{ Allele G } & $75(62.5)$ & $80(66.7)$ & 0.500 & 1.200 & 0.706 & 2.038 \\
\hline & Normal $(n=60)$ & CKD without CVD $(n=60)$ & $p$-value & OR & $95 \% \mathrm{Cl}$ & \\
\hline AA & $13(21.7)$ & $5(8.3)$ & Reference & & & \\
\hline AG & 19 (31.7) & $33(55.0)$ & 0.012 & 4.516 & 1.394 & 14.634 \\
\hline GG & $28(46.7)$ & $22(36.7)$ & 0.233 & 2.043 & 0.632 & 6.601 \\
\hline Allele A & $45(37.5)$ & $43(35.8)$ & Reference & & & \\
\hline \multirow[t]{2}{*}{ Allele G } & $75(62.5)$ & $77(64.2)$ & 0.789 & 1.074 & 0.635 & 1.817 \\
\hline & CKD without CVD $(n=60)$ & CKD with CVD $(n=60)$ & $p$-value & OR & $95 \% \mathrm{Cl}$ & \\
\hline AA & $5(8.3)$ & $1(1.7)$ & Reference & & & \\
\hline AG & $33(55.0)$ & $38(63.3)$ & 0.118 & 5.758 & 0.640 & 51.812 \\
\hline GG & $22(36.7)$ & $21(35.0)$ & 0.169 & 4.773 & 0.514 & 44.330 \\
\hline Allele A & $43(35.8)$ & $40(33.3)$ & Reference & & & \\
\hline Allele G & 77 (64.2) & $80(66.7)$ & 0.684 & 1.117 & 0.656 & 1.902 \\
\hline
\end{tabular}


Table 4: Frequency distribution of TCF7L2 (rs7903146) genotypes and alleles among the three studied groups

\begin{tabular}{|c|c|c|c|c|c|c|}
\hline Genotype & Normal $(n=60)$ & CKD without CVD $(n=60)$ & CKD with C & & & p-value \\
\hline $\mathrm{CC}$ & $29(48.3)$ & $21(35.0)$ & $14(23.3)$ & & & 0.009 \\
\hline CT & $27(45.0)$ & $29(48.3)$ & $29(48.3)$ & & & \\
\hline TT & $4(6.7)$ & $10(16.7)$ & $17(28.3)$ & & & \\
\hline & Normal $(n=60)$ & CKD without CVD $(n=60)$ & p-value & OR & $95 \% \mathrm{Cl}$ & \\
\hline CC & $29(48.3)$ & $21(35.0)$ & Reference & & & \\
\hline CT & $27(45.0)$ & $29(48.3)$ & 0.314 & 1.483 & 0.688 & 3.198 \\
\hline TT & $4(6.7)$ & $10(16.7)$ & 0.059 & 3.452 & 0.952 & 12.521 \\
\hline allele C & $85(70.8)$ & 71 (59.2) & Reference & & & \\
\hline allele T & $35(29.2)$ & $49(40.8)$ & 0.059 & 1.676 & 0.980 & 2.865 \\
\hline & Normal $(n=60)$ & CKD with CVD $(n=60)$ & $p$-value & OR & $95 \% \mathrm{Cl}$ & \\
\hline CC & $29(48.3)$ & $14(23.3)$ & Reference & & & \\
\hline CT & $27(45.0)$ & $29(48.3)$ & 0.058 & 2.225 & 0.974 & 5.080 \\
\hline TT & $4(6.7)$ & $17(28.3)$ & 0.001 & 8.804 & 2.492 & 31.105 \\
\hline Allele C & $85(70.8)$ & $57(47.5)$ & Reference & & & \\
\hline Allele T & $35(29.2)$ & $63(52.5)$ & $<0.001$ & 2.684 & 1.576 & 4.571 \\
\hline & CKD without CVD $(n=60)$ & CKD with CVD $(n=60)$ & $\mathrm{p}$-value & OR & $95 \% \mathrm{Cl}$ & \\
\hline CC & $21(35.0)$ & $14(23.3)$ & Reference & & & \\
\hline CT & $29(48.3)$ & $29(48.3)$ & 0.350 & 1.500 & 0.641 & 3.509 \\
\hline TT & $10(16.7)$ & $17(28.3)$ & 0.076 & 2.550 & 0.907 & 7.165 \\
\hline Allele C & $71(59.2)$ & $57(47.5)$ & Reference & & & \\
\hline Allele T & $49(40.8)$ & $63(52.5)$ & 0.071 & 1.602 & 0.961 & 2.669 \\
\hline
\end{tabular}

Table 5: Correlation between rs7069102 in SIRT1 genotypes in both CKD groups and the laboratory data

\begin{tabular}{|c|c|c|c|c|}
\hline \multirow[t]{2}{*}{ Parameters } & \multicolumn{3}{|c|}{ rs7069102 in SIRT1 } & \multirow[t]{2}{*}{$p$-value } \\
\hline & GG & CG & CC & \\
\hline BMI $\left(\mathrm{kg} / \mathrm{m}^{2}\right)$ & $26.13 \pm 4.71$ & $27.43 \pm 5.12$ & $26.74 \pm 4.22$ & 0.439 \\
\hline $\begin{array}{l}\text { Duration of } \\
\text { dialysis (years) }\end{array}$ & $7.86 \pm 3.82$ & $7.69 \pm 3.38$ & $8.66 \pm 3.26$ & 0.382 \\
\hline $\begin{array}{l}\text { Systolic blood } \\
\text { pressure }(\mathrm{mm} / \mathrm{Hg})\end{array}$ & $133.8 \pm 15.96$ & $134.16 \pm 11.16$ & $132.38 \pm 12.59$ & 0.837 \\
\hline $\begin{array}{l}\text { Diastolic blood } \\
\text { pressure }(\mathrm{mm} / \mathrm{Hg})\end{array}$ & $83.95 \pm 11.37$ & $84.22 \pm 8.12$ & $86.28 \pm 10.16$ & 0.562 \\
\hline Calcium (mg/dl) & $8.66 \pm 0.71$ & $8.45 \pm 0.96$ & $8.51 \pm 0.82$ & 0.505 \\
\hline Phosphorus (mg/dl) & $4.98 \pm 1.42$ & $5.24 \pm 1.64$ & $5.17 \pm 0.89$ & 0.683 \\
\hline Glucose (mg/dl) & $121.56 \pm 53.88$ & $125.91 \pm 40.47$ & $150.59 \pm 63.27$ & 0.045 \\
\hline Cholesterol (mg/dl) & $196.05 \pm 55.82$ & $220.96 \pm 54.93$ & $222.41 \pm 77.27$ & 0.100 \\
\hline Triglycerides (mg/dl) & $126.98 \pm 34.88$ & $133.40 \pm 35.49$ & $134.50 \pm 41.83$ & 0.618 \\
\hline \multicolumn{5}{|l|}{ ESRD Etiology (\%) } \\
\hline $\begin{array}{l}\text { Diabetic } \\
\text { nephropathy }\end{array}$ & $13(30.2)$ & $20(44.4)$ & $18(56.3)$ & 0.001 \\
\hline $\begin{array}{l}\text { Hypertensive } \\
\text { nephropathy }\end{array}$ & $16(37.2)$ & $21(46.7)$ & $5(15.6)$ & \\
\hline $\begin{array}{l}\text { Analgesic } \\
\text { nephropathy }\end{array}$ & $3(7.0)$ & $0(0.0)$ & $0(0.0)$ & \\
\hline Obstructive & $11(25.6)$ & $3(6.7)$ & $6(18.8)$ & \\
\hline \multicolumn{5}{|l|}{ Uropathy } \\
\hline Vasculitis & $0(0.0)$ & $0(0.0)$ & $3(9.4)$ & \\
\hline $\begin{array}{l}\text { Polycystic kidney } \\
\text { disease }\end{array}$ & $0(0.0)$ & $1(2.2)$ & $0(0.0)$ & \\
\hline
\end{tabular}

the role of two SNPs in the SIRT1 gene (rs706 9102 and rs10823108) in the development of cardiovascular

Table 6: Correlation between rs10823108 in SIRT1 in both CKD groups and the laboratory data

\begin{tabular}{|c|c|c|c|c|}
\hline \multirow[t]{2}{*}{ Parameters } & \multicolumn{3}{|c|}{ rs10823108 in SIRT1 } & \multirow[t]{2}{*}{$p$-value } \\
\hline & AA & AG & GG & \\
\hline BMI $\left(\mathrm{kg} / \mathrm{m}^{2}\right)$ & $23.72 \pm 5.22$ & $27.29 \pm 4.84$ & $26.35 \pm 4.40$ & 0.159 \\
\hline $\begin{array}{l}\text { Duration of } \\
\text { dialysis (years) }\end{array}$ & $8.17 \pm 2.23$ & $7.96 \pm 3.90$ & $8.07 \pm 2.99$ & 0.807 \\
\hline $\begin{array}{l}\text { Systolic blood } \\
\text { pressure }(\mathrm{mm} / \mathrm{Hg})\end{array}$ & $126.67 \pm 5.16$ & $133.55 \pm 12.42$ & $134.56 \pm 15.36$ & 0.401 \\
\hline $\begin{array}{l}\text { Diastolic blood } \\
\text { pressure }(\mathrm{mm} / \mathrm{Hg})\end{array}$ & $85.00 \pm 5.48$ & $83.24 \pm 9.22$ & $87.00 \pm 11.08$ & 0.144 \\
\hline Calcium (mg/dl) & $8.85 \pm 0.20$ & $8.43 \pm 0.89$ & $8.68 \pm 0.78$ & 0.188 \\
\hline Phosphorus (mg/dl) & $3.83 \pm 0.60$ & $5.30 \pm 1.45$ & $5.03 \pm 1.25$ & 0.036 \\
\hline Glucose (mg/dl) & $145.67 \pm 80.62$ & $132.04 \pm 47.93$ & $127.05 \pm 57.74$ & 0.700 \\
\hline Cholesterol (mg/dl) & $214.67 \pm 92.99$ & $222.62 \pm 60.74$ & $195.26 \pm 58.80$ & 0.076 \\
\hline \multicolumn{5}{|l|}{ ESRD Etiology (\%) } \\
\hline $\begin{array}{l}\text { Diabetic } \\
\text { nephropathy }\end{array}$ & $3(50.0)$ & $30(42.3)$ & $18(41.9)$ & 0.161 \\
\hline $\begin{array}{l}\text { Hypertensive } \\
\text { nephropathy }\end{array}$ & $1(16.7)$ & $30(42.3)$ & $11(25.6)$ & \\
\hline $\begin{array}{l}\text { Analgesic } \\
\text { nephropathy }\end{array}$ & $0(0.0)$ & $0(0.0)$ & $3(7.0)$ & \\
\hline $\begin{array}{l}\text { Obstructive } \\
\text { Uropathy }\end{array}$ & $2(33.3)$ & $9(12.7)$ & $9(20.9)$ & \\
\hline Vasculitis & $0(0.0)$ & $1(1.4)$ & $2(4.7)$ & \\
\hline $\begin{array}{l}\text { Polycystic kidney } \\
\text { disease }\end{array}$ & $0(0.0)$ & $1(1.4)$ & $0(0.0)$ & \\
\hline
\end{tabular}

complications in a group of CKD Egyptian patients. We demonstrated the presence of an association between the $C$ allele of the SIRT1 rs7069102 polymorphism and CVD development in CKD patients. There was a significant increase in the SIRT1 (rs7069102) CC genotypes and $C$ allele frequency among CKD patients with CVD than the normal control group and also a significant increase in the risk of CVD among CC genotype carriers $(\mathrm{OR}=15.167,95 \% \mathrm{Cl}=4.5-51.06$ and $p<0.001)$ and $C$ allele carriers $(O R=4.547,95 \%$ $\mathrm{Cl}=2.612-7.914$ and $\mathrm{p}<0.001)$. Moreover, there was a significant difference in the SIRT1 (rs7069102) genotypes frequency when compared between CKD patients with CVD and those without CVD $(p<0.001)$; as the CC genotype was significantly higher in CKD patients with CVD than in those without CVD, also we found that CC genotype carriers in CKD patients with CVD were at higher risk for CVD development when compared to CKD patients without CVD (OR $=8.089$ and $95 \% \mathrm{Cl}=2.728-23.983)$ and the same result was also found for $\mathrm{C}$ allele $(\mathrm{OR}=3.127$ and $95 \% \mathrm{Cl}=1.841$ 5.310); finding that CKD patients with CVD harboring

Table 7: Correlation between rs7903146 in TCF7L2 in both CKD groups and the laboratory data

\begin{tabular}{|c|c|c|c|c|}
\hline \multirow[t]{2}{*}{ Parameters } & \multicolumn{3}{|c|}{ rs7903146 in TCF7L2 } & \multirow[t]{2}{*}{$\mathrm{p}$-value } \\
\hline & CC & CT & TT & \\
\hline BMI $\left(\mathrm{kg} / \mathrm{m}^{2}\right)$ & $26.55 \pm 5.09$ & $27.02 \pm 4.93$ & $26.54 \pm 3.94$ & 0.861 \\
\hline $\begin{array}{l}\text { Duration of } \\
\text { dialysis (years) }\end{array}$ & $6.69 \pm 4.00$ & $8.07 \pm 3.18$ & $9.59 \pm 2.89$ & 0.001 \\
\hline $\begin{array}{l}\text { Systolic blood } \\
\text { pressure }(\mathrm{mm} / \mathrm{Hg})\end{array}$ & $133.89 \pm 12.03$ & $134.00 \pm 13.35$ & $132.22 \pm 15.21$ & 0.839 \\
\hline $\begin{array}{l}\text { Diastolic blood } \\
\text { pressure }(\mathrm{mm} / \mathrm{Hg})\end{array}$ & $82.03 \pm 11.14$ & $85.34 \pm 8.83$ & $86.67 \pm 10.00$ & 0.145 \\
\hline Calcium (mg/dl) & $8.70 \pm 0.77$ & $8.42 \pm 0.84$ & $8.60 \pm 0.90$ & 0.263 \\
\hline Phosphorus (mg/dl) & $5.20 \pm 1.32$ & $5.10 \pm 1.26$ & $5.10 \pm 1.74$ & 0.931 \\
\hline Glucose (mg/dl) & $130.14 \pm 41.83$ & $126.62 \pm 53.64$ & $141.22 \pm 64.43$ & 0.499 \\
\hline Cholesterol (mg/dl) & $198.20 \pm 46.50$ & $215.53 \pm 58.47$ & $224.15 \pm 84.81$ & 0.237 \\
\hline Triglycerides $(\mathrm{mg} / \mathrm{dl})$ & $121.17 \pm 33.56$ & $131.03 \pm 35.76$ & $145.41 \pm 40.17$ & 0.036 \\
\hline \multicolumn{5}{|l|}{ ESRD Etiology (\%) } \\
\hline $\begin{array}{l}\text { Diabetic } \\
\text { nephropathy }\end{array}$ & $15(42.9)$ & $22(37.9)$ & $14(51.9)$ & 0.540 \\
\hline $\begin{array}{l}\text { Hypertensive } \\
\text { nephropathy }\end{array}$ & $11(31.4)$ & $23(39.7)$ & $8(29.6)$ & \\
\hline $\begin{array}{l}\text { Analgesic } \\
\text { nephropathy }\end{array}$ & $1(2.9)$ & $1(1.70)$ & $1(3.7)$ & \\
\hline Obstructive & $8(22.9)$ & $10(17.2)$ & $2(7.4)$ & \\
\hline Uropathy & & & & \\
\hline Vasculitis & $0(0.0)$ & $1(1.7)$ & $2(7.4)$ & \\
\hline $\begin{array}{l}\text { Polycystic kidney } \\
\text { disease }\end{array}$ & $0(0.0)$ & $1(1.7)$ & $0(0.0)$ & \\
\hline
\end{tabular}


CC genotype and $C$ allele are more susceptible to develop CVD 15.167 and 4.5 times, respectively, than those with (GG/CG) genotypes.

Following our results, a study investigated the relationship between rs7069102 genetic polymorphism and the risk of myocardial infarction, showing that patients carrying the $\mathrm{C}$ allele of the rs7069102 have an increased risk of myocardial infarction. This study found that rs7069102 polymorphism could affect the expression of SIRT1 protein and CC genotype might lead to over-expression of SIRT1 protein in CVD patients; this increase in SIRT1 protein levels could be understood as a compensatory mechanism for enhancing the production of e-NOS to combat high levels of oxidative stress in CKD patients with CVD [14]. Another study revealed that CKD patients carrying the $\mathrm{C}$ variant of rs7069102 in the SIRT1 gene had an increased incidence of concentric left ventricular hypertrophy [15], which also comes in accordance with our results.

Regarding rs10823108 SNP in the SIRT1 gene, we found a significant association between the $A G$ and GG genotypes of rs10823108 in the SIRT1 gene and CVD development in CKD patients. The percentage of both $A G$ and $G G$ genotypes was significantly increased in CKD patients with CVD as compared to the normal control group ( $p=0.002$ and 0.035 , respectively). Carriers of GG genotype in the SIRT1 gene (rs10823108) are more susceptible to developing CVD than those with other SIRT1 rs10823108 genotypes (OR $=9.7$ and $95 \% \mathrm{Cl}=1.18-80.5)$, denoting that GG genotype' carriers of rs10823108 in the SIRT1 gene are 9.7 times more susceptible to develop CVD. Up to the best of our knowledge, our present study is the first one to investigate rs10823108 and CVD development in CKD patients.

The presence of an association of SIRT1 genetic polymorphisms with the pathogenesis and increased risk of diabetic kidney disease (DKD) and its complications was confirmed by recent studies. A recent study showed that the GG and AG genotypes in the rs10823108 locus were associated with increased DKD risk [16]. As well as the C allele, CC and CG genotypes of rs7069102 were more common in the group of diabetic nephropathy patients when compared with the GG genotype carriers (OR $=1.94$ and $p=0.02$ ) [17], which goes hand in hand with our study as we found a significant positive correlation between serum glucose levels and the CC genotype of rs7069102 in the SIRT1 gene $(p=0.034)$. Besides, SIRT1 induces lipolysis in the adipose tissue, insulin secretion, and insulin sensitivity, acting as a powerful anti-diabetic factor [18]. So that we can conclude that SIRT1 rs7069102 could be used as a genetic marker to assess the cardiovascular risk among diabetic nephropathy patients.

Moreover, we found that there is a significant positive correlation between serum phosphorus levels and the AG genotype of rs10823108 in the SIRT1 gene $(p=0.037)$. High serum phosphate level is a constant feature in CKD patients with CVD and has been significantly correlated with increased cardiovascular risk in CKD patients. Reduction of phosphate is crucial to prevent CVD risk in CKD patients [19]. Thus, it is vital to investigate the role of genetic polymorphisms that have a positive correlation with high levels of phosphorus in CKD patients with CVD as it might affect therapy. Hence, the importance of our study findings, which may indicate that the AG\& GG genotypes of rs10823108 could aid in CVD pathogenesis in CKD patients through elevation of serum phosphorus.

TCF7L2 is a member of a family of TCFs that have a role in the pathogenesis of CVD through modulation of smooth muscle cell proliferation. The TCF7L2 rs7903146 genetic polymorphism in the TCF7L2 gene was reported previously to be associated with diabetic coronary atherosclerosis and CKD progression to ESRD. Our study revealed a significant association between the $T$ allele and TT genotypes of rs7903146 in the TCF7L2 gene and CVD development in CKD patients. The TT genotype and T allele frequencies of rs7903146 in the TCF7L2 gene were significantly increased in CKD patients with CVD as compared to the normal control group ( $p<0.001$ and $<0.001$, respectively). Moreover, we found that rs7903146 in the TCF7L2 gene TT genotype and T allele carriers are 8.8 and 2.6 times, respectively, more susceptible to develop CVD (for TT genotype OR = 8.8, $95 \% \mathrm{Cl}=2.4-31.1$ and $p=0.001)$. A previous study performed on a group of ESRD patients with CVD compared to a healthy control group found a significant association between the TCF7L2 gene rs7903146 and risk of CVD occurrence in ESRD patients [20], which supported our results. Another study done on a group of CKD patients compared to a group of healthy controls showed that the T allele of the TCF7L2 gene rs7903146 is a genetic risk factor for CVD in CKD patients [21], which also comes in accordance with our results.

TCF7L2 is well-known to be one of the diabetes-susceptibility genes, it could elevate the risk of renal disease by two mechanisms, the first mechanism is through its effect on diabetes susceptibility, and DM furtherly will cause renal damage. The second mechanism is through the TCF4 protein, expressed by the TCF7L2 gene. TCF4 protein is important for kidney development and thus could affect the progression of kidney disease. These findings are supported by a study performed on 2 groups of diabetic patients, one group with DKD and the other group without DKD, which found that patients harboring the TT genotype of rs7903146 were at higher risk to acquire the nephropathy than the CC genotype carriers ( $p=0.02$ ), elucidating that the $T$ allele confers genetic risk to develop nephropathy and its complications such as CVD [22], which also come in accordance of our results. A recent study performed on CKD patients with CVD compared to healthy controls reported that the T allele of rs7903146 had a significant 
association with CVD development in CKD patients $(O R=2.2$ and $p<0.05)$ [21]. Another study performed on ESRD with CVD compared to a group of healthy controls found that CKD patients carrying the T allele of rs7903146 in the TCF7L2 gene were 1.57 times more susceptible for developing CVD than $C$ allele carriers (OR $=1.57$ and $95 \% \mathrm{Cl}=1.31-1.90)$, which comes in harmony with the results of our study [21].

As hypertriglyceridemia is one of the traditional risk factors for CVD development in CKD patients; Kulkarni et al., 2019 found that serum triglycerides levels were significantly increased in CKD patients with CVD as compared to normal controls, which is matched with our results as we elucidated a significant positive correlation between serum triglycerides levels and the TT genotype of TCF7L2 gene $(p=0.030)$, confirming that the T allele of rs7903146 in the TCF7L2 gene confers high risk for CVD development in CKD patients [21].

Our study was performed to assess the genetic polymorphisms as molecular risk factors in the pathogenesis of CVD in CKD patients. The exact mechanism which can fully explain the exaggerated prevalence of cardiovascular morbidity and mortality in patients with CKD is not fully understood yet. Therefore, traditional management of CVD in CKD patients is not enough to hinder the progression of CVD in these patients, so investigating genetic risk factors could have a significant impact on the treatment, and also we can use them for early prediction of CVD in diabetic patients to protect diabetic patients from both CKD and CVD.

Further research is needed to confirm our results and to clarify the impact of the studied SNPs on the pathogenesis and risk of CVD complications in CKD patients, and also to identify more genetic variants as they could be used as susceptibility markers for CVD in CKD patients.

\section{Conclusion}

To conclude, we found a significant role of rs7903146 in the TCF7L2 gene and SIRT1 rs7069102 and rs10823108 genetic polymorphisms in the development of cardiovascular events in CKD patients. This implies that these molecular variants could be used as markers for susceptibility for CVD development in CKD Egyptian patients.

\section{Acknowledgment}

Special thanks to Professor Dr. Huda Abo-Talib for her assistance in sample size calculation.

\section{References}

1. Provenzano M, Coppolino G, Nicola LD, Serra R, Garofalo C, Andreucci $\mathrm{M}$, et al. Unraveling cardiovascular risk in renal patients: A new take on old tale. Front Cell Dev Biol. 2019;7:314. https://doi.org/10.3389/fcell.2019.00314

PMid:31850348

2. Xie Y, Bowe B, Mokdad AH, Xian H, Yan Y, Li T, et al. Analysis of the global burden of disease study highlights the global, regional, and national trends of chronic kidney disease epidemiology from 1990 to 2016. Kidney Int. 2018;94(3):567-81. https://doi. org/10.1016/j.kint.2018.04.011

PMid:30078514

3. Webster AC, Nagler EV, Morton RL, Masson P. Chronic kidney disease. Lancet. 2017;389(10075):1238-52. https://doi. org/10.1016/S0140-6736(16)32064-5

PMid:27887750

4. Cañadas-Garre M, Anderson K, Mcgoldrick J, Maxwell A, Mcknight A. Proteomic and metabolomic approaches in the search for biomarkers in chronic kidney disease. J Proteomics. 2019;193:93-122. https://doi.org/10.1016/j.jprot.2018.09.020 PMid:30292816

5. Xue P, Cao H, Ma Z, Zhou Y, Wang N. Transcription factor 7-like 2 gene-smoking interaction on the risk of diabetic nephropathy in Chinese Han population. Genes Environ. 2021;43(1):26. https://doi.org/10.1186/s41021-021-00194-2

PMid:34193317

6. Kaur N, Bhatti GK, Kaur S, Bhadada SK, Singh S, Bhatti JS Transcription factor 7-like 2 genes, rs12255372 (G/T) variant and susceptibility to Type 2 diabetes mellitus in North Indians. Gene Rep. 2020;19:100595.

7. Morigi M, Perico L, Benigni A. Sirtuins in renal health and disease. J Am Soc Nephrol. 2018;29(7):1799-809. https://doi. org/10.1681/ASN.2017111218

PMid:29712732

8. Sosnowska B, Mazidi M, Penson P, Gluba-Brzózka A, Rysz J Banach M. The sirtuin family members SIRT1, SIRT3 and SIRT6: Their role in vascular biology and atherogenesis. Atherosclerosis. 2017;265:275-82. https://doi.org/10.1016/j. atherosclerosis.2017.08.027 PMid:28870631

9. Xiong $\mathrm{H}$, Chen S, Lai L, Yang H, Xu Y, Pang J, et al. Modulation of miR-34a/SIRT1 signaling protects cochlear hair cells against oxidative stress and delays age-related hearing loss through coordinated regulation of mitophagy and mitochondrial biogenesis. Neurobiol Aging. 2019;79:30-42. https://doi. org/10.1016/j.neurobiolaging.2019.03.013.

PMid:31026620

10. Chan $\mathrm{SH}$, Hung $\mathrm{CH}$, Shih JY, Chu PM, Cheng YH, Lin HC, et al. SIRT1 inhibition causes oxidative stress and inflammation in patients with coronary artery disease. Redox Biol. 2017;13:3019. https://doi.org/10.1016/j.redox.2017.05.027 PMid:28601780

11. Kristensen VN, Kelefiotis D, Kristensen T, Børresen-Dale AL. High-throughput methods for detection of genetic variation. Biotechniques. 2001;30(2):318-32, 324, 326. https://doi. org/10.2144/01302tt01

PMid:11233601

12. Chan YH. Biostatistics 102: Quantitative data-parametric and non-parametric tests. Singapore Med J. 2003;44(8):391-6.

13. Chan YH. Biostatistics 103: Qualitative data-tests of Independence. Singapore Med J. 2003;44(10):498-503.

PMid:15024452 
14. Yamac $A H$, Uysal $O$, Ismailoglu Z, Ertürk $M$, Celikten $M$, Bacaksiz A, et al. Premature myocardial infarction: Genetic variations in SIRT1 affect disease susceptibility. Cardiol Res Pract. 2019;2019:8921806. https://doi.org/10.1155/2019/8921806 PMid:31143479

15. Spoto B, Ntounousi E, Testa A, Liakopoulos V, D'Arrigo G, Tripepi G, et al. The sirtuin1 gene associates with left ventricular myocardial hypertrophy and remodeling in two chronic kidney disease cohorts. J Hypertens. 2018;36(8):1705-11. https://doi. org/10.1097/HJH.0000000000001746

PMid:29702498

16. Yue XG, Yang ZG, Zhang Y, Qin GJ, Liu F. Correlations between SIRT1 gene polymorphisms and diabetic kidney disease. R Soc Open Sci. 2018;5(6):171871. https://doi.org/10.1098/ rsos. 171871

PMid:30110438

17. Letonja J, Završnik M, Makuc J, Šeruga M, Peterlin A, Cilenšek I, et al. Sirtuin 1 rs7069102 polymorphism is associated with diabetic nephropathy in patients with Type 2 diabetes mellitus. Bosnian J Basic Med Sci. 2021;21(5):642-6. https://doi. org/10.17305/bjbms.2020.5368 PMid:33577446

18. Kurylowicz A. In search of new therapeutic targets in obesity treatment: Sirtuins. Int J Mol Sci. 2016;17(4):572. https://doi. org/10.3390/ijms 17040572

PMid:27104517

19. Zhou C, Shi Z, Ouyang N, Ruan X. Hyperphosphatemia and cardiovascular disease. Front Cell Dev Biol. 2021;9:644363. https://doi.org/10.3389/fcell.2021.644363

PMid:33748139

20. Buraczynska M, Zukowski P, Ksiazek P, Kuczmaszewska A Janicka J, Zaluska W. Transcription factor 7-like 2 (TCF7L2) gene polymorphism and clinical phenotype in end-stage renal disease patients. Mol Biol Rep. 2014;41(6):4063-8. https://doi. org/10.1007/s11033-014-3275-6

PMid:24574000

21. Kulkarni S, Lenin M, Ramesh R, Delphine SW, Velu K. Evaluation of single-nucleotide polymorphisms of transcription factor 7-like 2 and ATP2B1 genes as cardiovascular risk predictors in chronic kidney disease. Int $\mathrm{J}$ Appl Basic Med Res. 2019;9(4):221-5. https://doi.org/10.4103/ijabmr. IJABMR_92_19

PMid:31681547

22. Zhuang $Y$, Niu F, Liu D, Sun J, Zhang X, Zhang J, et al Associations of TCF7L2 gene polymorphisms with the risk of diabetic nephropathy. Medicine (Baltimore). 2018;97(40):e8388. https://doi.org/10.1097/MD.0000000000008388

PMid:30290587 